\title{
書字モードと筆圧・筆速の関係について
}

\author{
小野瀬 雅 人 $^{1}$
}

\section{A STUDY ON THE RELATION BETWEEN HANDWRITING MODE AND HANDWRITING PRESSURE-VELOCITY}

\author{
Masato ONOSE
}

Two experiments were conducted to investigate the relations between handwriting mode (tracing and copying) and handwriting pressure-velocity. In experiment I, kindergartners $(N=20)$ and undergraduate students $(N=20)$ were required to write a Kanji five times in each mode employing handwriting pressure device (TAKEI KIKI co. make). In experiment II, undergraduate students $(N=20)$ were required to write a Hangul character (Korean), unfamiliar character to subjects, using the same procedure. The results showed that there was a significant difference in handwriting pressure-velocity between kindergartner and undergraduate groups with regard to the handwriting mode. Discussed on the basis of the model of information processing on handwriting behavior (Schmidt, 1982 ; Stelmach, 1982), the results of two experiments suggested that the tracing mode made the burden too heavy for the response execution stage in that model as compared with copying mode. It was concluded that handwriting in tracing mode was a more difficult task than the copying mode for kindergartners.

Key words : handwriting pressure and velocity, tracing, copying, kindergartner, undergraduate.

\section{問題と目的}

入門期の文字練習用ワークブックでしばしば用いら れる教材をみると, 点線で印刷された文字の上からな ぞって書く「なぞり」や，実線で印刷された文字を手 本としてそれを見ながら書く「視写」が見受けられる。 こうした教材をワークブックに採用するのは，これら を使った練習が究極的には，手掛かりなしでも文字が 書けることを目的としているからにほかならない。つ まり，文字を記憶すると同時に，正しく字形を整えて 書くという運動技能を高めることも狙っているのであ

1 鳴門教育大学学校教育学部 (Faculty of School Education, Naruto University of Education)
る。

小野瀬 $(1987,1988)$ は，それらの教材を教室における 学習実験に持ち込み，その効果を検討している。すな わち，練習用教材として「なぞり」と「視写」を用い， それらを通常のクラスに割り当て，4 つの文字をそれ ぞれ 1 日 5 回ずつ練習するセッションを 3 日から 5 日 にわたって実施した。練習の前後に行ったテスト課題 として，手本を数秒見た後で書くときには手本を見ず に書く「自由書字」課題で検討したところ, 幼稚園児 と, 小学校 1 年生の 1 学期で書字の入門期にある児童 では，ワークの最初の段階で多く採用される「なぞり」 よりも「視写」の方が書字技能（文字を正しく字形を整え て書く能力）の習得に効果があることが認められた。

効果のあった理由としては，就学前の幼児のように 
手先の運動技能が十分発達していない段階では,「なぞ り」練習は困難な課題であるため，それを行うことに のみ集中し，その結果文字の全体像の記憶を含む認知 プロセスへの注意が拡散されてしまうが，「視写」練習 では文字を書く際に絶えず文字の全体像をイメージ化 させる必要がある。そのため書字技能のように手本な しで文字を書くことを要求する課題では「視写」練習 の効果が優れていた（小野瀬, 1988, p133）と考えられた。 しかし，この研究では，「なぞり」や「視写」のような 課題を用いて書く際の 1 回ごとのプロセスまでは検討 していないため,この解釈の妥当性に関しては問題点 として残された。

ところで, 最近では書字行動の情報処理メカニズム を解明する目的で「なぞり」や「視写」のような書字 モードを取り上げた研究も目立つ。これらの研究では 書字行動の情報処理モデルを仮定し，こうした異なる モードで書くときの筋力配分や時間配分を測定するこ とによって，モデルの検討を行っている。

書字行動の情報処理モデルとしては, 書字動作が「知 覚，反応選択，反応プログラミング，反応実行，環境 情報からのフィードバック」という過程を経て行われ るとするモデル (Schmidt, 1982 ; Stelmach, 1982) や，さ らに「反応選択，反応ブログラミング」のプロセスを 精緻化し「長期記憶からの運動プログラミングの検索, 関係するコードのパラメータ化，書字課題の実行に適 切な筋肉ユニットと神経の補充」の 3 段階を想定する モデル (Van Galen \& Teulings, 1983) も提出されている。

Shek, Kao, \& Chau（1986）は，これらの情報処理モ

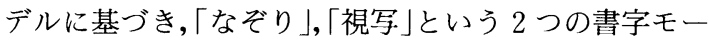
ドを使って，その過程にかかる負荷の大きさを検討し ようとした。すなわち，「なぞり」では文字上をそのま まトレースするため, 反応実行段階で手先の筋肉に対 してょり多くの要求を課すが，「視写」では，これに関 する限り「なぞり」ほど厳格ではない。つまり，正し さの基準がそれほど明瞭ではないので，反応選択には いくつか自由度が許されている。したがって,「なぞり」 動作の開始・実行のほうが，「視写」より大きな量の筋 肉活動に関与するため筆圧も大きくなり，上述のよう なプロセスに要する時間も長くなる，という仮説を検 討した。大学生32名を被験者として検討した結果，筆 圧・筆記時間ともに，「なぞり」モードの方が「視写」 モードょりも大きいことが確かめられた。一方，南 (1976a, b) は，この筆圧を書字作業におけるエネルギー 消費の指標として用い，筆圧が就学後は 6 か月くらい まで比較的高い $(600 \sim 700 \mathrm{~g})$ が，書字を中心とした学校
学習に慣れたそれ以降の段階では半減することを明ら かにしている。

以上の研究は，いずれも筆圧と筆速の両方あるいは そのどちらか一方を測度として用いているが，入門期 段階の幼児・児童の書字技能を高めるための教材とい う視点がないため，小野瀬 $(1987,1988)$ の得た結論に対 して，これら書字モードの影響の背後にあるメカニズ ムに関して示唆を与えないものとなっている。すなわ ち, Shek et al. (1986) の研究は，「なぞり」と「視写」 という書字モードを取り上げているが，被験者として 大学生しか用いていない。一方，南は，小学生を被験 者としているが，鉛筆の芯の硬度と筆圧の関係を発達 的に検討しているだけで，「なぞり」や「視写」のよう な書字モードについてはまったく触れていないのであ る。

そこで, 本研究では, 先行研究の多くが成人の書字 行動の情報処理メカニズムを解明しょうとした研究で あったために見落とした「入門期段階の教材としての 適切さ」という観点から，書字モードと筆圧・筆速の 関連性をとりあげ検討する。

書字の入門期にある幼児を対象として「なぞり」や 「視写」のような書字モードを用いて書く際の筆圧と 筆速を測定した研究は皆無であるが，この時期の幼览 であっても先行研究 (Schmidt, 1982 ; Shek et al., 1986 Stelmach, 1982; Van Galen \& Teulings, 1983）が提出した書 字行動の情報処理モデルによる説明が可能なら，筆圧 と筆速に関して次のような仮説が成立つだろう。すな わち，「『なぞり』は環境からフィードバックが『視写』 に比べより明確になされる (Stelmach) ため，それに基 づいて微細な修正を行わざるを得ない。そのため，反 応実行段階においてより多くの手先の筋肉が関与する ことになり，その結果，筆圧も高くなる。(仮説 1$)$ 」。同 時に,「微細な修正に要する時間もかかるため筆速も遅 くなる(仮説 2)」と考えられる。

本研究の目的は，書字の入門期段階にある幼児と書 字能力が完成した段階にある大学生 (成人)を対象に上 述の仮説を検討し，入門期段階の教材としてどちらの 書字モードが適切かについての理論的背景を明らかに することにある。

\section{実 験 I}

\section{目的}

書字の入門期にあると考えられる就学前の幼児と, 書字学習が完成した段階にあると考えられる大学生を 被験者として「なぞり」，「視写」という 2 つ書字モー 
ドで筆圧・筆速を測定し，上述の仮説を検討する。 方法

被験者 幼稚園年長組の幼児 20 名（男子 10 名, 女子 10 名; 平均年歯 5 歳 8 只) と大学生 20 名（男子 10 名, 女子 10 名)。

実験計画 個別実験。筆圧は 2 (学年: 幼児, 大学生) $\times$ 2 (書字モード : なぞり, 視写) $\times 4$ （ストローク:1,2,3,4）の 混合計画。学年が被験者間要因で, 書字モードとスト ロークが被験者内要因 2 である。筆速は2（学年: 幼児, 大学生) $\times 2$ （書字モード：なぞり, 視写）の混合計画。 学年が被験者間で, 書字モードが被験者内要因である。

材料・課題 漢字の「牛」 1 字。これは小学校 2 年 生で学習される漢字であるため, 被験者である幼児に とって新奇な文字であると考えられること, ストロー ク数 (画数) が少なく, しかも文字の要素 (綎線, 横線, 斜 線)を比較的多く含んでいることにより選ばれた。課題 は「なぞり」と「視写」で, サイズが約 $2.5 \times 2.5 \mathrm{~cm}$ の ものを用いた（FIGURE 1)。

装置 筆圧・筆速測定器 (竹井機器製, 「筆圧測定器III型」, FIGURE 2)。

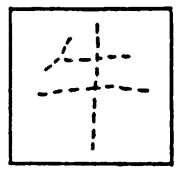

(a) なぞり課題 ( $t$ racing task)

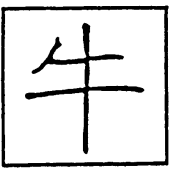

(b) 視写課題 (copying task)
FIGURE 1 漢字を材料としたなぞり課題と視写課題

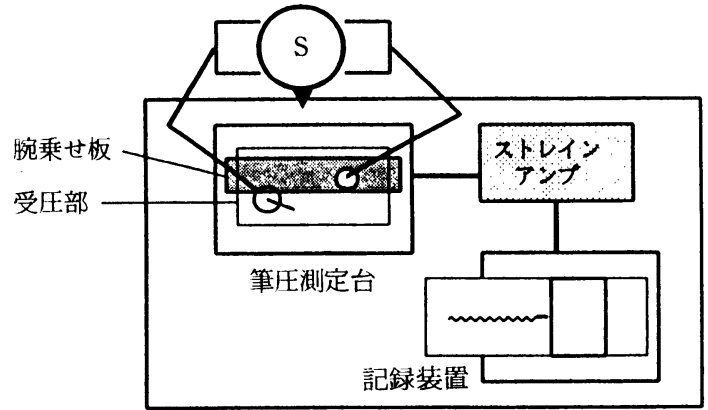

FIGURE 2 筆圧・筆速测定装置

\footnotetext{
本実験に先だって被験者間計画（両課題とも各 10 名）で測定し たが，個人差が大きい（なぞり：M=251.7, $S D=114.1 ＼mathrm{~ ; ~ 視 ~}$ 写: $M=316.2, S D=145.4 ）$ ため被験者内要因とした。
}

手続 まず，何も書かれていない白紙に被験者の氏 名を書くよう教示し装置に慣れたあとで（名前が書けな い幼児の場合は，まるや四角などの図形を書かせることにした）， 漢字の「牛」を 5 回「なぞり」または「視写」で書く よう被験者に求めた。その際, 書き始める直前に筆順 を教え，そのとおりに書くよう教示した。すなわち， 「これは漢字の牛という字です。この牛という字を今 やってみせた順序で, 点線の上からなぞって下さい(手 本と同じものをとなりに書いて下さい)。」と教示した。

また，本実験では，2つの書字モード「なぞり」，「視 写」を被験者内要因としたため,「なぞり」から始める 者と「視写」から始まるものをランダムにした。この ようにして書かれた文字の筆圧と筆速は, 同時に装置 を通して記録された (筆圧の単位 : $10 \mathrm{~g} / \mathrm{mm}$ )。データの分 析には, 5 回書いた文字の各ストロークごとの最大筆 圧と記録装置の紙送り速度 $(250 \mathrm{~mm} / \mathrm{min})$ より換算される 筆記速度の平均値を用いた。

なお，5回の平均值を測度として採用したのは，同 様の機器を使用して筆圧を測定した宮崎・広瀬・中島・ 園田・酒井（1984）の「健常者での筆圧でも変動が激し いので，同じ文字を何回か書かせその平均値を用いる のがよい」との指摘にしたがったことによる。

\section{結果と考察}

被験者ごとに 5 回ずつ測定された，「牛」を構成する 4 ストロークそれぞれの平均筆圧と，1 文字を書くの に要した時間，すなわち平均筆速の平均值を TABLE 1 に示す。平均筆圧について, 2 (学年: 幼児, 大学生) $\times 2$ (書字モード : なぞり, 視写) $\times 4$ （ストローク；1４）の分散 分析を行った。その結果, ストロークの主効果, 学年 と書字モードの交互作用が有意であった〔それぞれ，

TABLE 1 なぞり,視写モードでの筆圧・筆速 (材料：牛)

\begin{tabular}{|c|c|c|c|c|c|c|c|}
\hline & & & & 筆 & 圧 ${ }^{i 1}$ & & \\
\hline & & & 1 & 2 & 3 & 4 & \\
\hline & たズり & $M$ & 196.16 & 257.40 & 273.66 & 303.60 & 10.56 \\
\hline 奻 旧 & & $S D$ & 65.22 & 100.77 & 100.75 & 121.18 & 4.22 \\
\hline & 祖 写 & $M$ & 230.20 & 288.80 & 305.10 & 331.58 & 8.47 \\
\hline & & $S D$ & 81.90 & 107.41 & 111.93 & 144.75 & 3.39 \\
\hline & なぞり & $M$ & 264.42 & 334.08 & 377.00 & 386.72 & 4.98 \\
\hline & & $S D$ & 74.85 & 89.08 & 98.44 & 115.00 & 2.22 \\
\hline 人子手 & & $M$ & 233.20 & 287.05 & 320.95 & 319.85 & 3.69 \\
\hline & & $S D$ & 65.48 & 70.81 & 80.60 & 89.03 & 1.90 \\
\hline
\end{tabular}

注 1 : 筆圧は各ストロークごとのペン先にかかる重さ $(\mathrm{g})$ を示す。 注 2 ：筆速は 1 文字 $(4$ ストローク) を書くのに要した総時間 $(\mathrm{sec})$ を示す。 
$F(1,38)=15.37, p<.01 ; F(3,114)=64.12, p<.01] 。$ 学年と書字モードの交互作用で有意差が認められたの で, LSD 法 (MSe $=1512.58,5 \%$ 水準) による多重比較を 行った結果，幼児では「なぞりく視写」であったが, 大学生では「なぞり>視写」であることが明らかになっ た。また「なぞり」と「視写」のいずれもストローク (筆順) が後になるほど筆圧が大きくなることが明らか となった。

さらに, TABLE 1 のデータが示すように筆圧, 筆速 ともに個人差が大きいことから，それを考慮し，筆圧 の結果についてノンパラメトリックによる分析を行つ てみた。すなわち「なぞり」と「視写」の間で差のあっ た被験者(「なぞりの測定偡一視写の測定値」で「十」であった 者の数; TABLE 2a, TABLE 2b） とそれ以外の被験者との間 で各ストロークごとに，2 (幼児・大学生) $\times 2$ (差が十の 者·差がーの者) の直接確率を算出した結果，ストローク 1 〜のいずれも人数に有意な偏りが認められ(それぞ れ, $p=.0036 ; p=.0019 ; p=.0104 ; p=.0108$, いずれも両側検定), 分散分析の結果と同様, 幼児では「なぞり」より「視 写」の方が筆圧の大きい者が多く, 大学生では「視写」 より「なぞり」の方が筆圧の大きい者が多い，という 結果を得た。したがって, 大学生では Shek et al. の 先行研究と同様の結果を得たが, 幼児では反対で,「視 写」で書く方が「なぞり」で書くよりもより大きな筆 圧になることが確かめられた。

一方，筆速についても，筆圧と同様，TABLE 1 に基 づいて， 2 (学生: 幼児, 大学生) $\times 2$ (書字モード: なぞり， 視写)の分散分析を行ったところ, 学年扔よび書字モー ドの各主効果が有意であった〔それぞれ， $F(1,38)=$ $32.20, F(1,38)=17.38$, いずれもp<.01)。したがっ

TABLE 2a なぞりと視写の筆圧差の分布（人数）

\begin{tabular}{|c|c|c|c|c|}
\hline 筆压差生、ストローク & 1 & 2 & 3 & 4 \\
\hline$+1 \sim+49$ & 4 & 0 & 3 & 0 \\
\hline$+50 \sim+99$ & 0 & 3 & 1 & 6 \\
\hline$+100 \sim$ & 0 & 1 & 1 & 2 \\
\hline 計 & 4 & 4 & 5 & 8 \\
\hline \pm 0 & 0 & 1 & 0 & 0 \\
\hline$-1 \sim-49 g$ & 10 & 3 & 6 & 5 \\
\hline$-50 \sim-99$ & 4 & 7 & 6 & 2 \\
\hline$-100 \sim$ & 2 & 5 & 3 & 5 \\
\hline 計 & 16 & 15 & 15 & 12 \\
\hline
\end{tabular}

注:表中の数值は「なぞりの筆圧一視写の筆圧」。
TABLE 2b なぞりと視写の筆圧差の分布（人数）

\begin{tabular}{|c|c|c|c|c|}
\hline 筆圧差非、ストローク & 1 & 2 & 3 & 4 \\
\hline$+1 \sim+49 g$ & 7 & 4 & 5 & 6 \\
\hline$+50 \sim+99$ & 3 & 7 & 3 & 3 \\
\hline$+100 \sim$ & 4 & 4 & 6 & 7 \\
\hline 計 & 14 & 15 & 14 & 16 \\
\hline \pm 0 & 0 & 0 & 0 & 0 \\
\hline$-1 \sim-49$ & 6 & 3 & 3 & 2 \\
\hline$-50 \sim-99$ & 0 & 2 & 3 & 1 \\
\hline$-100 \sim$ & 0 & 0 & 0 & 0 \\
\hline 計 & 6 & 5 & 6 & 3 \\
\hline
\end{tabular}

注:表中の数値は「なぞりの筆圧一視写の筆圧」。

て，幼児・大学生ともに「なぞり」と「視写」では「な ぞり」の方がより大きな筆記時間を要し，いずれの書 字モードにおいても，大学生よりも幼児のほうがより 多くの筆記時間を要することが明らかとなった。

さらに，筆速では，筆圧のように被験者の学年によ り測定値に逆転がみられなかったので，個人差を考虑 し「なぞり」での筆速が「視写」でのそれょり大きかっ た人数をみたところ,分散分析の結果と同様,「なぞり」 で書く方が「視写」で書くよりも多くの時間を要する 被験者が多いことが示された。すなわち，幼児では20 名中16名 ( $p=.0018$ : 両側検定), 大学生では20名中17名 $(p=.0026$ : 両側検定) が，「視写」で書くよりも「なぞり」 で書くほうが多くの時間を要することが確かめられた。 以上から, 大学生では, 仮説 1 , 仮説 2 ともに支持 されたが，幼児では仮説 2 のみ支持されたといえる。

\section{実 験 II}

\section{目的}

実験 I で用いた漢字材料は，幼児にとっては未習熟 の文字であったが, 大学生にとっては十分習熟し, か つ書き慣れている文字であった。そこで，本実験では， 大学生にとって未習熟の文字であるハングル文字を用 いて筆圧・筆速を測定し, 実験 I と同様の仮説を検討 する。

\section{方法}

被験者 大学生 20 名 (男子 8 名, 女子 12 名)。 実験計画 個別実験。筆圧は 2 （書字モード：なぞり， 視写) $\times 3$ （ストローク：1，2，3）の被験者内計画。筆速は 1 要因 2 水準（書字モード：なぞり, 視写) の被験者内計 画。 
材料・課題 ハングル文字「가」の「なぞり」と「視 写」(FIGURE 3)。

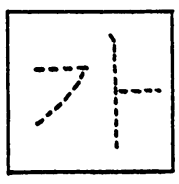

(a) なぞり課題 (tracing task)

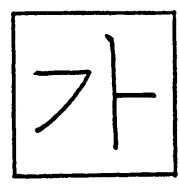
(copying task) (b) 視写課題

FIGURE 3 ハングル文字を材料としたなぞり課題と視写課題

\section{装置 実験 I と同じ。}

手続 前述のように，本実験は，成人にとって未習 熟であると仮定されるハングル文字の「가」を材料と したので，それを確認するため，各被験者に対して実 験終了後, ハングル文字についての学習経験の有無, 書く際に新奇な文字とみなしていたか否かを確かめる ことにした。すなわち，これまで読んだり書いたりし た経験の有無を問うことにより確かめた。その他の手 続は実験 I と同じである。

\section{結果と考察}

実験材料であるハングル文字䏠新奇な文字であると みなして書いた被験者のデータについて，実験 I と同 様,「가」構成する 3 ストロークそれぞれの 5 回の平 均筆圧と, 1 文字を書くのに要した時間, すなわち筆 速の平均値を TABLE 3 に示す。

TABLE 3 なぞり，視写モードでの筆圧・筆速

\begin{tabular}{|c|c|c|c|c|c|}
\hline \multirow{2}{*}{\multicolumn{2}{|c|}{ ストローク }} & \multicolumn{3}{|c|}{ 筆 压 ${ }^{\sharp 1}$} & \multirow{2}{*}{ 筆速到2 } \\
\hline & & 1 & 2 & 3 & \\
\hline \multirow{2}{*}{ なぞり } & $M$ & 324.82 & 334.43 & 408.64 & 4.77 \\
\hline & $S D$ & 65.22 & 100.77 & 100.75 & 1.07 \\
\hline \multirow{2}{*}{ 視 写 } & $M$ & 270.07 & 293.98 & 346.14 & 3.97 \\
\hline & $S D$ & 88.02 & 96.73 & 105.36 & 1.21 \\
\hline
\end{tabular}

注 1 ：筆压は各ストロークごとのペン先にかかる重さ ( g ) を示す。

注 2 : 筆速は 1 文字 $(4$ ストローク)を書くのに要した 総時間 $(\mathrm{sec})$ を示す。

まず筆圧について TABLE 3 に基づき，2（書字モード :なぞり, 視写) $\times 3$ (ストローク: 1,2,3）の分散分析を行っ たところ, 書字モードの主効果とストロークの主 効果が有意であった〔それぞれ $F(1,19)=11.26, F$
$(2,38)=55.62$, いずれも $p<.01]$ 。ストロークの要因に ついて LSD 法 $(M S e=1278.23,5 \%$ 水準 $)$ による多重比較 を行った結果，筆圧の大きさは「ストローク $1<$ くト ローク $2<$ くトローク 3 」であった。したがって，筆 圧の大きさは「なぞり>視写」で，筆順が後になるほ ど大きくなることが示された。

さらに測定值の個人差が大きいことを考慮し，実験 I と同様，まず「なぞり」と「視写」の間で差があっ た被験者（「なぞりの測定值一視写の測定值」で「十」であった 者の数; TABLE 4) とそれ以外の被験者との間で直接確率 を算出した結果，第 1 ，第 3 ストロークで人数に有意 な偏りが認められたが（それぞれ, $p=.0026, p=.0414$, いず れも両側検定)，第 2 ストロークでは有意差はなかった ( $p=.1153$, 両側検定)。

TABLE 4 なぞりと視写の筆圧差の分布（人数） 〔材料：ハングル文字「가」；被験者：大学生20名〕

\begin{tabular}{cccc}
\hline 筆圧差生 $\backslash$ ストローク & 1 & 2 & 3 \\
\hline$+1 \sim+49 g$ & 9 & 6 & 6 \\
$+50 \sim+99$ & 5 & 5 & 4 \\
$+100 \sim$ & 3 & 3 & 5 \\
計 & 17 & 14 & 15 \\
\hline \pm 0 & 0 & 0 & 0 \\
\hline$-1 \sim-49$ & 2 & 6 & 4 \\
$-50 \sim-99$ & 1 & 0 & 1 \\
$-100 \sim$ & 0 & 0 & 0 \\
計 & 3 & 6 & 5 \\
\hline
\end{tabular}

注：表中の数値は「なぞりの筆圧一視写 の筆圧」。

以上のことから，いずれのストロークも実験 I と同 様,「なぞり」で書くほうが「視写」で書くよりもより 大きな筆圧を示した被験者が多く, したがって, 大学 生では「視写」よりも「なぞり」で書くほうが, 反応 実行の段階でより多くの筋力を要するものと考えられ る。

一方，筆速についても，TABLE 3 に基づき「なぞり」 と「視写」で書いたときの平均值について $\mathrm{t}$ 検定を行っ たところ, $t(19)=3.60(p<.01)$ で有意差が認められ た。

さらに実験 I と同様, 個人差を考慮し「なぞり」で の筆速が「視写」より大きかった人数の偏りを直接確 率を求めて検討したところ， $\mathrm{t}$ 検定の結果と同様，「な ぞり」で書く方が「視写」で書くよりも多くの時間を 
要する被験者が多いことが示された（20名中 17 名; $p=$ .0026 , 両側検定)。つまり漢字を材料とした実験 I と同 様, 大学生では「なぞり」で書くほうが「視写」に比 べより多くの時間を要することが明らかになった。

したがって, 仮説 1 , 仮説 2 ともに支持されたとい える。

\section{全体の考察}

「なぞり」,「視写」という2つの書字モードで文字を 書く際の筆圧・筆速を, 書字経験の少ない就学前の幼 児と, 書字経験を十分積んだ大学生を被験者として測 定した。その結果, 大学生では先行研究の結果と同様 の結果を得たが，就学前の幼児ではとくに筆圧で全く 反対の結果を得た。すなわち大学生では仮説 1 ・ 2 と もに支持されたが，幼児では仮説 2 しか支持されな かった。そこで，ここでは，筆圧と筆速に分け，2つ の実験結果を総合して考察することにしたい。

\section{1. 筆圧について}

「なぞり」と「視写」で書く際に, 紙面にどの程度の 力がかかっているかを示す筆圧については, 大学生で はShak et al. (1986) と同様の結果を得た。すなわち, 習熟している漢字でも，そうでないハングル文字でも， 「なぞり」で書くほうが「視写」で書くよりも大きな筆 圧で書く者が有意に多かった。このことは, 反応実行 段階で「なぞり」による書字動作に厳しい運動制御の 要求があることを反映しているものと考えられる。つ まり，この結果は，線からの逸脱を許さない「なぞり」 動作の負担の大きさを物語っているものと思われる。

一方, 幼児では, 大学生の結果とは反対で,「なぞり」 よりも「視写」での書字動作の方が大きい筆圧を示す 者が有意に多かった。南 (1976a，b）の研究結果と同様, ペン先にかかる圧を筆圧とし，それをエネルギー消費 の指標とみなしたとき,「なぞり」の方がより大きな筆 圧になるものと考えていたが，結果は反対であった。

ところで, Harris \& Rarick（1957）は，筆圧には(1) ペン先にかかる圧, (2)ペを握る指の圧(握圧), (3)用紙 の上で支える手に付随する圧，の 3 側面があると考え ている。つまり, ペン先にかかる圧は, 筆圧のひとつ の面であり, 書字の際に力のかかる部分は他にもある と指摘する。

そこで,この見解も考慮に入れて本実験の結果を再 検討したところ，幼児では同じ被験者の書いた文字 1 つにつき 3 回以上, FIGURE 4 に示すような「ゆれ」が みられた者の数が,「視写」では 20 名中 4 名であったの に対し，「なぞり」では20名中16名であることが判明
し, 一方, 大学生では漢字, ハングル文字ともに「ゆ れ」はみられなかった。前述の(2)(3)部分に過剰な力 が入る, あるいは緊張が生じた場合, それによって書 かれる文字に「ゆれ」が生じることが考えられるが, もしそうであるならば，この結果は，幼児の場合では ペン先にかかる圧以外の部分に力がかかっていたこと を示すものと解釈できるだろう。

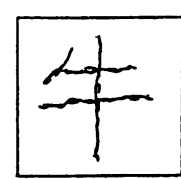

(a) なぞり課題 ( $\mathrm{t}$ racing task)

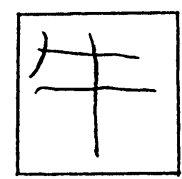
(copying task) (b) 視写課題

FIGURE 4 なぞり課題にみられる筆跡の“ゆれ”(左側) (同一被験者の書字サンプル)

このように，幼児では鉛筆をはじめとする筆記具を 操作する技能が未熟であったために，圧がペン先にス トレートにかからず，ペンを握る指や手先全体の筋に より大きな緊張が生じたものと考えられる。そのため 力が入り過ぎ, 逆にペン先にかかる筆圧が小さくなつ たものと思われる。

「なぞり」を実行する際の筆圧で幼児より大学生の方 が大きくなったことについては，幼児では「なぞり」 を実行する際に筆跡に「ゆれ」が現れるほど極度の緊 張を手先に強いられるためストレートにペン先に力が 入らなくなることを示し，大学生では逆に手先が緊張 しペン先に力が入り過ぎたことによると考えられる。 したがって, 幼児と大学生の手先の運動技能の差が予 想以上に大きいことが示唆される。

なお, ストロークが後になるほど筆圧が高まる傾向 は, 幼児, 大学生ともにみられたが, これに関しては 現時点ではその妥当な解釈がみあたらないため, 今後 の検討課題としたい。

\section{2.筆速について}

「なぞり」「視写」で書く際の筆速 (筆記時間) につい ては, 幼児・大学生ともに, Shek et al.の結果と同様, 「なぞり」の方が「視写」に比べて長い時間を要する者 が多かった。この結果は, 最初に紹介した書字行動の 情報処理モデルの反応実行段階で，「なぞり」が「視写」 より多くの筋肉が関与することにより，微細な修正に 必要とされる時間も増した結果と考えられる。

また,幼児と大学生で筆記時間を比べると,「なぞり」 
では, 幼児が平均10.56秒 ( $S D: 4.22)$ であるのに対し, 大学生は漢字が平均 4.98 秒 $(S D: 2.22)$, ハングル文字 が平均4.47秒 ( $S D: 1.07)$ であった。一方,「視写」で は, 幼児が平均 8.47 秒 $(S D: 3.39)$ であるのに対し大学 生は, 漢字が平均 3.69 秒 $(S D: 1.90)$, ハングル文字が 平均3.97秒 ( $S D: 1.21)$ であった。さらに, 各被験者ご との「なぞり」と「視写」の差をみると, 幼児では平 均 3.29 秒 $(S D: 2.71)$, 大学生では漢字が平均 1.49 秒 ( $S D$ $: 1.09$ ), ハングル文字が平均 0.92 秒 $(S D: 0.88)$ であっ た。このことから筆圧の測定結果と同様, 大学生に比 べ幼児では 2 つの書字モード間では，書字行動の情報 処理モデルの反応実行段階で関与する筋肉への負担に かなりの差があるといえるだろう。

\section{3. まとめと今後の課題}

「なぞり」と「視写」という $2 つ の$ 書字モードで書く 際の筆圧・筆速を検討した結果，当初設定した仮説は 一部を除いて支持された。すなわち，幼児においても 先行研究と同様, 筆圧という測度が手先の運動への負 荷を反映すると考えていたが，幼児では大学生とは反 対で，筆圧が小さくなる傾向がみられた。そこで，実 際に幼児が「なぞり」モードで書いた筆跡をみると， 筆跡に「ゆれ」をともなう者が多かった。これは書字 の際に手先の筋肉に対し過剩な負荷がかかったため, ペン先にストレートに力がかからず，それゆえ筆圧低 下を招いたものと考えられた。

この結果は, 幼児においても大学生と同様, 1 回の 書字動作を行う際の情報処理過程, すなわち書字行動 の情報処理モデル (Schmidt, 1982 ; Stelmach, 1982 ; Van Galen \& Teulings, 1983）の反応実行過程に対してより大 きな負荷がかかることを示唆するものであるが，同時 に, 幼児や児童を対象に行った教室場面での学習実験 で示された「なぞり」の効果が「視写」に比べ低かっ たことの理論的証拠となると考えられる。

書字モードが書字行動の情報処理モデルの中でどの ような役割を果たすのかに関して,その詳細を明らか にするためには，さらに多様な材料と測度〔例えば EMG (Electromyography : 筋電図)など〕を用いての検討 が必要であろう。なぜなら, 先行研究が示唆したよう に, 大学生では手先への運動的負荷が大きいほど筆圧 も大きくなるが，幼児では逆に筆圧が小さくなること もあるからである。その意味では，筆圧という測度の 限界を示すものといえる。

しかし「なぞり」や「視写」のような書字モードが, 実際に入門期の幼児・児童向けのワークブックで多く 採用されていることを考えると，その意義に関しても，
さらに検討の余地があるものと思われる。つまり，書 字習得の過程で，とくにその技能が未熟な段階にある 幼児や児童の手先により大きな負担を強いる「なぞり」 を，教材としてどのように考えるか，ということであ る。南(1976b) も指摘するように, 書字に際して抵抗が あったり, 精神的疲労が累積されると, 書字能力を下 げるばかりか学習能率を下げ, ひいては学習意欲も阻 害されることになるからである。

\section{引用文献}

Harris, T.L., \& Rarrick, L. 1957 The problem of pressure in handwriting. Journal of Experimental Education, 26, 151-178.

南哲 $1976 \mathrm{a}$ 鉛筆に関する教育生理学的研究 第一報 鉛筆筆記の習熟段階と筆圧変化の経緯 学校保健研究, 18, 175-183.

南 哲 $1976 \mathrm{~b}$ 鉛筆に関する教育生理学的研究 第三報 鉛筆硬度および学年・性差の筆圧に及ほ す影響に関する研究 学校保健研究, 18, 288 -296 .

宮崎珠子・広瀬容子・中島富美子・園田啓示・酒井ひ とみ 1984 健常者の利手, 非利手による書字の 筆圧 第 18 回日本作業療法士学会

小野瀬雅人 1987 幼児・児童におけるなぞり及び視 写の練習が書字技能の習得に及济す効果 教育心 理学研究, 35, 9-16.

小野瀬雅人 1988 なぞり及び視写練習の組合わせが 幼児・児童の書字技能に及ほす効果 教育心理学 研究, 36, 129-134.

Schmidt, R.A. 1982 Motor control and learning : $A$ behavioral emphasis. Ill : Human Kinetics Publishers.

Shek, D.T.L., Kao, S.R., \& Chau, A.W.L. 1986 Attentional resources allocation process in different modes of handwriting control, In Kao, H.S.R., Van Galen, G.P., Hoosain, R. (Eds) Graphonomics : Contemporary research in handwriting, North-Holland.

Stelmach, G.E. 1982 Information-processing framework for understanding human behavior. In Kelso, A.S. (Ed.) Human Motor Behavior : An Introduction, N.J. : Lawrence Erlbaum.

Van Galen, G.P. \& Teulings, H.L. 1983 The independent monitoring of form and scale factors in handwriting. Acta Psychologica, 54, 9-22. 
付 記

本研究をまとめるにあたり適切な助言を戴いただけ でなく, 測定装置についても便宜をおはかり戴いた筑 波大学心理学系教授・福沢周亮先生に深く感謝致しま す。また，実験の実施にあたりご協力いただいた千葉
県柏市学校法人くるみ学園・くるみ幼稚園の先生方な らびに園児の皆さん, 筑波大学人間学類の学生諸氏に 厚く御礼申し上げます。なお, 本実験の一部は, 日本 教材学会第 5 回大会 (1993) で発表した。

(1994，10.24受稿，12.12受理) 